\title{
Analysis of Household Food Security in Indonesia New Capital City (Kutai Kartanegara and North Penajam Paser)
}

\author{
Archadius Permata Pakerti ${ }^{1} \quad$ Yunastiti Purwaningsih ${ }^{2} \quad$ Akhmad Daerobi $^{2}$ \\ 1.Student of Master Economics and Development Studies, Faculty of Economics and Business \\ 2.Lecturer of Agricultural Economics, Faculty of Economics and Business, \\ Sebelas Maret University, Ir Sutami Street 36 A, Surakarta, Indonesia
}

\begin{abstract}
The Government of Republic Indonesia plans to move The Capital from Jakarta to East Kalimantan especially in Regency of Kutai Kartanegara and Noth Penajam Paser. It is suspected that the relocation of the capital has implications and implications for both Regencies. Liu (2013) introduced the term tele-coupling as an interaction strategy between socio-economic environments in the combined human-nature in a region that causes various impacts, where food security is one of the impacts that need to be considered. The focus of this research is to analyze factors that significantly affect household food security. This research uses data of Economic Social Survey (Susenas) 2020 Core Module and Consumption-Expenditure Module, data analysis techniques using Multinomial Logistic Regression Analysis for each household according to food security levels, where food secure households become a reference category (base outcome). The results showed that food security of insecure households is influenced by factors: wages, employment, household members, the agricultural sector, the industrial sector, and the service sector significantly. While the food security of less secure households is influenced by factors of wages, education, household members, age, domicile, marital status, and gender significantly. While food security of vulnerable households is influenced by factors of wages, employment, household members, age, and the service sector significantly.
\end{abstract}

Keywords: Food Security, Household, Indonesia New Capital

DOI: $10.7176 / \mathrm{JESD} / 12-22-02$

Publication date: November $30^{\text {th }} 2021$

\section{Introduction}

Food security is an interesting phenomenon to research, especially when there is a migration of population from old region to new region, because the availability of sufficient food becomes a vital need to sustain survival in new region.

The government has scheduled the transfer of the State Capital from DKI Jakarta to East Kalimantan Province precisely in Regency of Kutai Kartanegara and North Penajam Paser by 2024. The relocation of the state capital is thought to have profound impacts and implications for both Regencies. Liu (2013) introduced the term telecoupling, which is a socio-economic environmental interaction in a combination of natural-human systems in a region that causes various impacts, from the impacts that arise food security decline to one of the impacts that need to be considered (Jianguo Liu et al., 2013). Of course, the Government and National Planning Agency (Bappenas) have conducted research before establishing the transfer of the State Capital, because the agenda of moving the National Capital has been included in the National Long Term Development Plan 2020-2024.

The migration factor is thought to be a significant factor to affect the deterioration of food security levels, by moving the capital will certainly trigger mass migration from bureaucrats, state apparatus both civilian and police and army, businessmen and their families, and so on. The Food and Horticulture Office of East Kalimantan Province noted that in 2017 there was a rice deficit of 151,976 tons. Meanwhile, the availability of land in Regency of Kutai Kartanegara and North Penajam Paser is consecutively covering an area of 27,263.1 $\mathrm{km}^{2}$ and 3,333.06 $\mathrm{km}^{2}$ is fixed, so the development of urban planning needs to pay attention to the use of land for food needs in addition to the construction of office complexes, residential, and infrastructure.

Based on the results of the Inter-Census Population Survey (SUPAS) by the Central Statistics Agency (BPS) it is projected that the population growth of East Kalimantan Province significantly increase significantly by $130 \%$ during the period 2015 to 2045 (BPS-RI, 2018).

In addition to the projected population growth that continues to increase, there is another problem in East Kalimantan, such as the lack of food uniformity consumed by the community. The Publication of Food Security Statistics noted that rice consumption always ranks first from 2015 to 2019. This means that during the period 2015-2019 the people of East Kalimantan only consume one type of food, such as rice, this is quite alarming because of the potential for balanced nutritional deficiency. Because the supply of nutritious and affordable food triggers opportunities for people to be more food secure. The figure below describes the graph of food consumption based on the most dominant foodstuffs for the period 2015-2019 in East Kalimantan, the data is processed from the Publication of Food Security Statistics and obtained from the Food Security Agency of the Republic of Indonesia (BKP-RI, 2019). 
However, the dominance of rice food consumption was not followed with rice production and the area of harvest land that should also increasing, this indicates that so far, the consumption of community rice is fulfilled by import factors from other regions. Data on rice production and the extent of East Kalimantan's harvest showed stagnant growth. This is certainly alarming because, in 2024 the National Capital will be moved to East Kalimantan, of course the problem of food security aspects of Food Availability needs to be considered so that the new capital could avoids food shortage disasters.

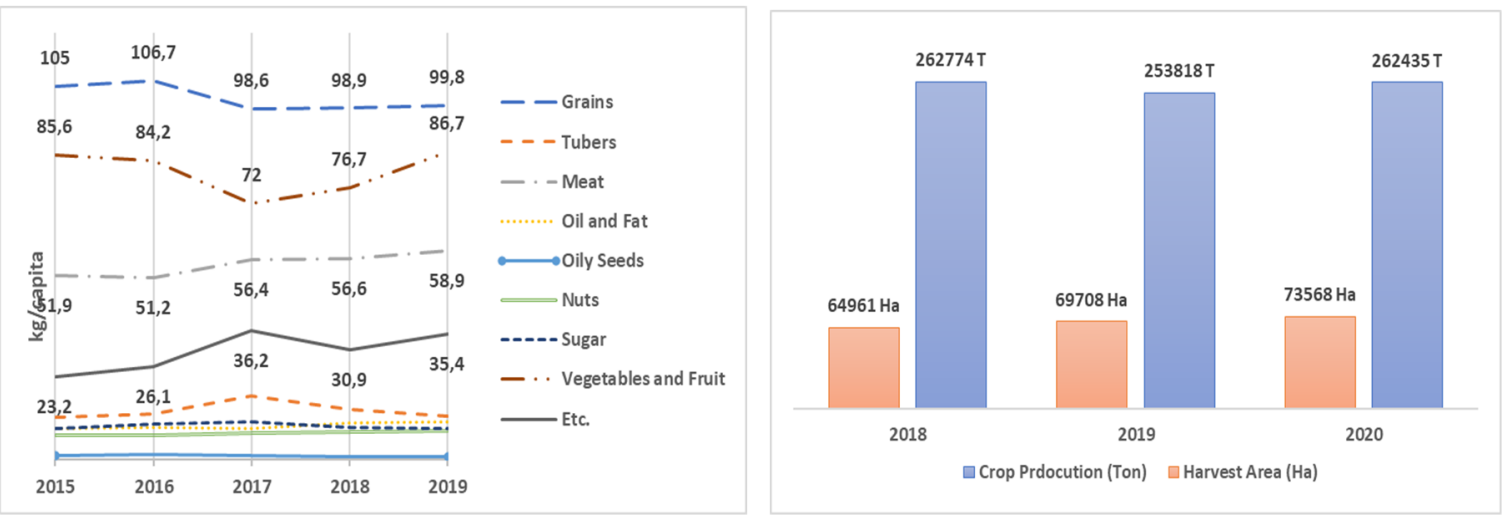

Figure1. Food Consumption based on foodstuffs Source: BPS Susenas 2015-2019, processed and justified by the expenditure approach by BKP in Food Security Statistics 2019

Based on the phenomenon supported by data above, it can be said that research on food security is still relevant to be done, especially if it is associated with the phenomenon of relocation the capital city, so that this research scheme is quantitative research with the main topic of food security, the purpose of this research is: Analyzing factors that significantly affect food security level in each household according to the level of security of food security in Regency of Kutai Kartanegara and North Penajam Paser.

\section{Literature Review}

Food is everything that comes from the biological resources of agricultural products, plantations, forestry fisheries, livestock, well-processed / unprocessed waters intended as food / beverage for human consumption, including food reserves, food raw materials, and other materials used in the process of preparing, processing and making food beverage (Undang-undang Nomor 18 Tahun 2012 tentang Pangan, 2012). This law of food also defines Food Security as the conditions of food fulfillment for the country up to the benefits reflected by the availability of sufficient food, both the amount and quality is safe, nutritious, equitable, and affordable and not contrary to the religion, beliefs, and culture of the community, for healthy, active, and productive living in a sustainable manner (Undang-undang Nomor 18 Tahun 2012 tentang Pangan, 2012). Another concept by Peter Warr (2014) defines food security which is divided into four levels, such as: Global Level is the adequacy of the amount of food offered to meet food in aggregate. National level is the ability of a country to be more food secure by balancing the demand for food quantities in aggregate. Household level is the ability of a household in accessing adequate food at all times. Individual level is the ability of the household in distributing food to the level of individuals who belong to the members of the household or the ability of an individual in obtaining food within the scope of the household (Warr, 2014).

The household is the smallest unit in society consisting of the husband and wife and their children, the father (widower) and the child, the mother (widow) and her child (Undang-undang Nomor 52 Tahun 2009 tentang Perkembangan Kependudukan dan Pembangunan Keluarga, 2009). Another concept defines households as a form of living affairs that are done together and led by a household's head who is elected according to customs and traditions (Murniati et al., 2004). Which household food security can be defined as the ability of households to meet food needs, so that household food security is influenced by factors such as: food prices, household size, income, education, and domicile (Herdiana et al., 2014; Suharyanto et al., 2014).

Many research analyzing about factors that affect food security, the first is the research on determinants of food security on rice farming households in Bali by Suharyanto (2014) analyzed factors such as maternal education level, income, household food reserves proved to have a significant positive effect on food security, while factors in the size of household members, rice prices, and instant noodle prices, member of households significantly negative affected to food security (Suharyanto et al., 2014). Furthermore, factors that have a correlation with the household food security, especially farmers household are: rice production, and the length of education of the husband has a strong positive correlation with household food security, while household revenue and crop area 
have a weak positive correlation with household food security, while household members and food expenditure have negative correlation with household food security (Hernanda et al., 2017). Furthermore, the results of research on determinants of household food security by Nanda (2019) analyzed factors such as: income, rice prices, other consumption prices significantly positive affect to household food security, while the size of household member and price of food factors significantly negative affect household food security (Nanda et al., 2019). The results of another food security research by Anisya (2019) analyzed the following factors: tempeh-tofu prices, and the size of household members significantly negatively affect the food security of agricultural households (Anisya et al., 2019). While factors such as age, gender, education level, remittances, unemployment rate, inflation, asset ownership, and acting outbreaks showed significant influence on household food security (Abdullah et al., 2019). Similarly on rural households, where the following factors: Employment or unemployed status, the size of household members, and family hope programs (PKH) significantly negatively affect household food security, while the economic status of households significantly affects household food security (Syamola et al., 2019). While recent research by Fitriani (2020) in barn farmers' households showed that rice production factors and freelance jobs significantly affect food security, while rice price factors significantly negatively affect food security (Fitriani et al., 2020). Another recent research by Abdurehim (2021) showed that the following factors: gender of the head of household, education level, household size, donkey ownership, commercial crop production, household income, income outside the agricultural sector, access to irrigation, and frequency of extension contacts significantly positively affect the food security of rural households. (Abdurehim et al., 2021)

\section{Method}

\subsection{Scope}

The focus of this research is to analyze factors that significantly affect food security in each household according to the level of food security where there are four categories, such as: food-insecure households, food-less secure households, food-vulnerable households, while food-secure households as the reference category (base outcome).

This research was conducted in East Kalimantan Province which become the next capital replaced Jakarta, precisely in Regency of Kutai Kartanegara and North Penajam Paser. The landmass of East Kalimantan covers an area of $127,346.92 \mathrm{~km}^{2}$ and is located between $113^{\circ} 35^{\prime} 31^{\prime \prime}$ east longitude to $119^{\circ} 12^{\prime} 48^{\prime \prime}$ east longitude and $2^{\circ} 34^{\prime} 23^{\prime \prime}$ north latitude to $2^{\circ} 44^{\prime} 14^{\prime \prime}$ south latitude astronomically. This following presented a map of East Kalimantan Province by figure 3 .

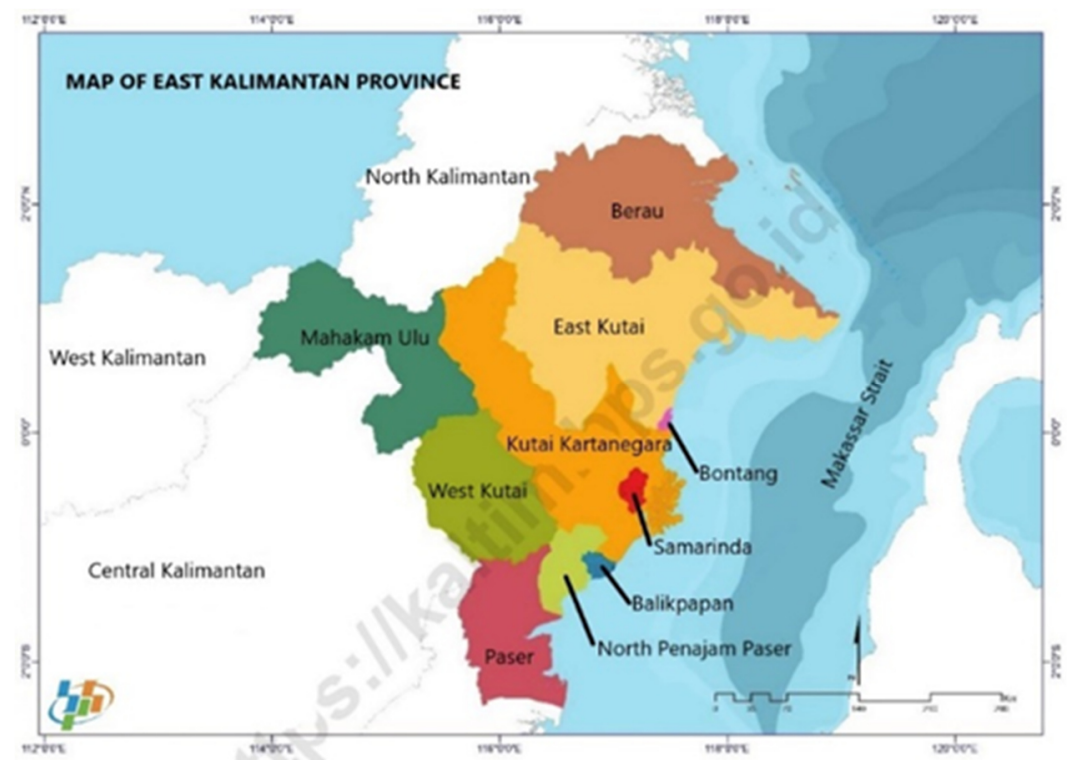

Figure 3. Map of East Kalimantan Province

Source: BPS, in East Kalimantan Publications in Figures 2019

\subsection{Data}

The data used is Susenas 2020 Core Module and Consumption-Expenditure Module, obtained through the official website of the https://silastik.bps.go.id/ (Statistic Services System). The reason for the use of Susenas data because of the size of the research respondents is large and diverse also the data is updated every year so that the Susenas data is relevant enough to reflect the current household conditions. The respondents selected in this research were households domiciled in Regency of Kutai Kartanegara and North Penajam Paser.

Susenas is a National Socio-Economic Survey whose activities was conducted every year, in all provinces in 
Indonesia (34 provinces) with a sample size of 320,000 households spread across 514 Regency/cities throughout Indonesia. In particular, the respondents of this research amounted to 1256 households, spread across Kutai Kartanegara Regency as many as 713 respondents, and a total of 543 respondents in North Penajam Paser Regency.

\subsection{Data Analysis Methods}

This research adopts quantitative methods using 12 variables consisting of one dependent variable and 11 independent variables. The dependent variable on this research is the level of food security calculated using the degree of food security which is a method of measuring food security by collaborating two factors, such as the share of food expenditure and energy consumption capita, where cutting point share of food expenditure of $60 \%$ of total expenditure, and cutting point of energy consumption by $80 \%$ of the energy adequacy(Jonsson et al., 1991)

The Government of the Republic of Indonesia through the Ministry of Health regulates that the average recommended energy consumption for the people of Indonesia is $2100 \mathrm{kcal}$ (Permenkes 28 Tahun 2019 tentang AKG, 2019). The Data Susenas 2020 Consumption-Expenditure Module has provided variable of calories (energy consumption $/ \mathrm{kcal}$ ) so that this research is facilitated by not needing to calculating value of energy consumption. While the food expenditure share factor is calculated by using the following equation:

$$
\text { Share of Food Expenditure }=\frac{\text { Food Expenditure }}{\text { Total Expenditure }} \times 100 \%
$$

The result of collaboration of food expenditure factors produces a matrix of degrees food security which presented in table 1 below:

Table1. Degree of Food Security

\begin{tabular}{lll}
\hline \multirow{2}{*}{$\begin{array}{l}\text { Energy Consumption (energy adequacy 2100 } \\
\text { kcal) }\end{array}$} & \multicolumn{2}{l}{ Share of Food Expenditure } \\
\cline { 2 - 3 } & $\begin{array}{l}\text { Low }<60 \% \text { total } \\
\text { expenditure }\end{array}$ & $\begin{array}{l}\text { High } \geq 60 \% \text { of total } \\
\text { expenditure }\end{array}$ \\
\hline Enough $>80 \%$ energy adequacy & Food-Secure & Food-Vulnerable \\
\hline Less $\leq 80 \%$ energy adequacy & Food-Less Secure & Food-Insecure \\
\hline
\end{tabular}

Source: Jonsson, Toole (1991)

Based on table 1 above it is known that there are four categories of food security, such as: food-secure, foodvulnerable, food-less secure, and food-insecurity. Here's a full explanation of each of these categories. First, foodsecure is when the low share of food expenditure and consumes enough energy. Second, food-vulnerability is when the high share of food expenditure but consumes enough energy. Third, food-less secure is when the low share of food expenditure but less energy consumption. Fourth, food-insecure is when the high share of food expenditure and consumes less energy.

The data analysis technique using Multinomial Logistic Regression Analysis (Polytomous Logistic Regression), where the 11 independent variables that will be analyzed their effect on food security as dependent variables. The reason for the use of this technique because, this research aims to analyze factors that significantly affect food security in each household according to the level of food security, such as food-vulnerable households, food-less secure households, and food-insecure households. While food secure households will be a reference category (base outcome). This multinomial logistic regression analysis process assisted by STATA 16. The forms of multinomial logistic regression equations are:

$$
z_{j}(x)=\operatorname{Ln}\left[\frac{P(Y=j \mid x)}{P(Y=i \mid x)}\right]=\beta_{j i}+\beta_{j 1} x_{1}+\beta_{j 2} x_{2}+\beta_{j 3} x_{3}+\beta_{j 4} x_{4}+\beta_{j 5} x_{5} \ldots+\beta_{j n} x_{n} ; j=1,2,3 i=0
$$

Description

$P(Y=j \mid x)$ : the odds of the terms of the dependent variable $j$ in vector $x$.

$\mathrm{P}(\mathrm{Y}=\mathrm{i} \mid \mathrm{x})$ : the opportunity of the terms of the dependent variable $\mathrm{i}$ in the reference category (base outcome).

$z \mathrm{j}(\mathrm{x}) \quad$ : logit on the dependent variable $\mathrm{j}$, where $\mathrm{j}=0,1,2,3$ etc.

$x_{\mathrm{n}:} \quad$ : value of $\mathrm{n}$ independent variable.

$\beta_{\mathrm{jn}:} \quad$ : coefficients of regression equations.

The research expects that the following factors: Wages, Education, Employment, Household Members, Age, Domicile, Agricultural Sector, Industrial Sector, Service Sector, Marital Status, and Gender significantly affect food security. More characteristics of independent variables and their expected sign are presented in table 2 below: 
Table2. Operational Definitions of Variables and Hypotheses

\begin{tabular}{|c|c|c|c|c|}
\hline Description of Variables & Data Type & Notation & Unit Description & $\begin{array}{l}\text { Expected } \\
\text { Sign }\end{array}$ \\
\hline $\begin{array}{l}\text { Dependent Variables: } \\
\text { Food Security Level (FSL) }\end{array}$ & Ordinal & $\begin{array}{l}\mathrm{P}_{(\mathrm{Y}=0)} \\
\mathrm{P}_{(\mathrm{Y}=1)} \\
\mathrm{P}_{(\mathrm{Y}=2)} \\
\mathrm{P}_{(\mathrm{Y}=3)}\end{array}$ & $\begin{array}{l}\text { 0: Food-secure as base outcome } \\
\text { 1: Food-Insecure } \\
\text { 2: Food-Less Secure } \\
\text { 3: Food-Vulnerable }\end{array}$ & \\
\hline \multicolumn{5}{|l|}{ Independent Variables } \\
\hline Wages & Continuous & $\mathrm{X}_{1}$ & Rupiah (IDR) & + \\
\hline Education & Dichotomous & $\mathrm{X}_{2}$ & $\begin{array}{l}0 \leq \text { elementary, junior high, } \\
1 \geq \text { high school, vocational } \\
\text { school, diploma }\end{array}$ & + \\
\hline Employement & Dichotomous & $\mathrm{X}_{3}$ & 0: Employee. 1: Entrepreneur. & + \\
\hline Household Member & Dichotomous & $\mathrm{X}_{4}$ & $0 \geq 5$ people. $1 \leq 4$ people. & + \\
\hline Age & Continuous & $\mathrm{X}_{5}$ & Years. & - \\
\hline Domicile & Dichotomous & $\mathrm{X}_{6}$ & $\begin{array}{l}\text { 1: Kutai Kartanegara. 0: North } \\
\text { Penajam Paser. }\end{array}$ & - \\
\hline Agricultural Sector & Dichotomous & $\mathrm{X}_{7}$ & 1: Agriculture. 0: Others. & - \\
\hline Industrial Sector & Dichotomous & $\mathrm{X}_{8}$ & 1: Industry. 0: Others. & + \\
\hline Service Sector & Dichotomous & $\mathrm{X}_{9}$ & 1: Services. 0: Others. & + \\
\hline Marital Status & Dichotomous & $\mathrm{X}_{10}$ & 1: Married. 0: Others. & - \\
\hline Gender & Dichotomous & $\mathrm{X}_{11}$ & 1: Male. 0: Female. & + \\
\hline
\end{tabular}

Source: Literature Review (2021)

\section{Results and Discussions}

\subsection{Household Distribution by Food Security Level}

Based on the results of data analysis Susenas 2020 Core Module and Consumption-Expenditure Module that assisted by STATA, it is known that the distribution of 1256 household respondents spread across Kutai Kartanegara and North Penajam Paser, which is classified according to food security levels. Total distribution of food-secure households is known to be 681 households, spread across Kutai Kartanegara as many as 402 households and as many as 279 households spread across North Penajam Paser. Total distribution of foodvulnerable households is known to be 282 households, spread across Kutai Kartanegara as many as 170 households and as many as 112 households spread across North Penajam Paser. Total distribution of food-less secure households is known to be 249 households, spread across Kutai Kartanegara as many as 116 households and as many as 133 households spread across North Penajam Paser. Total distribution of food-insecure households is known to be 44 households, spread across Kutai Kartanegara as many as 25 households and as many as 19 households spread across North Penajam Paser. More description of household's distribution by food security level is presented in table 3 below:

Table 3. Distribution of Households by Food Security Level

\begin{tabular}{lccr}
\hline Food Security Level & Kutai Kartanegara & North Penajam Paser & Total \\
\hline Food-Secure & 402 & 279 & 681 \\
\hline Food-Vulnerable & 170 & 112 & 282 \\
\hline Food-Less Secure & 116 & 133 & 249 \\
\hline Food-Insecure & 25 & 19 & 44 \\
\hline Amount & 713 & 543 & 1256 \\
\hline
\end{tabular}

Source: Susenas 2020 processed using STATA

\subsection{Factors Affecting Household Food Security}

The main focus in this research is analyzing the significant factors affecting the level of food security of foodvulnerable households, food-less secure households, and food-insecure households, the stages of multinomial logistic regression analysis techniques, starting from model summary test, parameter tests, and relative risk ratios test (odds ratio).

\subsubsection{Model Summary}

The Model Summary conducted to find out as well as an empirical model able to explain variations in food security levels by a series of independent variables. The test results were shown at a Pseudo $\mathrm{R}^{2}$ of $0.1265(12.65 \%)$, meaning that a series of independent variables in the empirical model were able to explain the variation in food security rate of $12.65 \%$ while the remaining $87.35 \%$ is explained by other variables outside the model. Furthermore, 
to find out whether a set of independent variables significantly affects the dependent variables simultaneously, are shown at a Likelihood Ratio of 351.19 with a Prob> Chi2 value of 0,000 smaller than alpha 5\% (0.05) meaning that a set of independent variables significantly affects the dependent variables of food security levels simultaneously. More model summary results are presented in table 4 below:

Table 4. Model Summary

\begin{tabular}{lr}
\hline Model Summary & Value \\
\hline Observation & 1256 \\
\hline Log Likelihood & -1212.91 \\
\hline Likelihood Ratio Chi $^{2}(33)$ & 351.19 \\
\hline Prob. $>\mathrm{Chi}^{2}$ & 0.000 \\
\hline Pseudo R & 0.1265 \\
\hline urce: Susenas 2020 processed using STATA
\end{tabular}

\subsubsection{Parameter Estimates}

Source: Susenas 2020 processed using STATA

The Parameter Estimates test conducted to find out whether each independent variable significantly affects the dependent variables. Shown in the wald (z) test value which refers to each of the following households:

\section{Parameter Estimates on Food-Vulnerable Households}

The results of the wald (z) test showed that factors such as wages, employment, household members, age, and the service sector significantly affected the level of food security, this is evidenced in the consecutively of wald (z) test value known as $-8.52 ; 2.41 ;-4.32 ;-3.15 ; 1.64$ with $\mathrm{P}$ value of $\mathrm{P}>|\mathrm{z}|$ known as $0.00 ; 0.01 ; 0.00 ; 0.00 ; 0.10$ are smaller than alpha 5\% (0.05). More results are presented in table 5 below:

Table 5. Parameter Estimates on Food-Vulnerable Households

\begin{tabular}{llrrr}
\hline Variable & Notation & Coefficient & Wald (z) & $\mathbf{P}>|\mathbf{z}|$ \\
\hline Wages & $\mathrm{X}_{1}$ & -1.34 & -8.52 & $* 0.00$ \\
\hline Education & $\mathrm{X}_{2}$ & 0.01 & 0.06 & 0.95 \\
\hline Employment & $\mathrm{X}_{3}$ & 0.40 & 2.41 & $* 0.01$ \\
\hline Household Member & $\mathrm{X}_{4}$ & -7.73 & -4.32 & $* 0.00$ \\
\hline Age & $\mathrm{X}_{5}$ & -0.02 & -3.16 & $* 0.00$ \\
\hline Domicile & $\mathrm{X}_{6}$ & -0.03 & -0.22 & 0.82 \\
\hline Agricultural Sector & $\mathrm{X}_{7}$ & -0.28 & -0.77 & 0.44 \\
\hline Industrial Sector & $\mathrm{X}_{8}$ & 0.41 & 1.11 & 0.26 \\
\hline Service Sector & $\mathrm{X}_{9}$ & 0.60 & 1.64 & $* * 0.10$ \\
\hline Marital Status & $\mathrm{X}_{10}$ & 0.31 & 0.82 & 0.41 \\
\hline Gender & $\mathrm{X}_{11}$ & 0.21 & 0.50 & 0.61 \\
\hline \multicolumn{1}{c}{ Constanta } & & 1.68 & 2.74 & 0.00 \\
\hline
\end{tabular}

Source: Susenas 2020 processed using STATA

Note: **significant at $10 \% *$ significant at $5 \%$

\section{Parameter Estimates on Food-Less Secure Households}

The results of the wald (z) test showed almost all factors in the model, such as wages, education, household members, age, domicile, marital status, and gender significantly affect the level of food security, this is evidenced in the consecutively of wald $(\mathrm{z})$ test value known as $-3.59 ;-3.54 ;-1.66 ;-2.11 ;-2.89 ;-2.64 ; 2.89$ with $\mathrm{P}$ value of $\mathrm{P}>|\mathrm{z}|$ known as $0.00 ; 0.00 ; 0.09 ; 0.03 .0 .00 ; 0.00 ; 0.00$ are smaller than alpha 5\% (0.05). More results are presented in table 6 below: 
Table 6. Parameter Estimates on Food-Less Secure Households

\begin{tabular}{llrrr}
\hline Variable & Notation & Coefficient & Wald (z) & $\mathbf{P}>|\mathbf{z}|$ \\
\hline Wages & $\mathrm{X}_{1}$ & -3.79 & -3.59 & $* 0.00$ \\
\hline Education & $\mathrm{X}_{2}$ & -0.62 & -3.54 & $* 0.00$ \\
\hline Employment & $\mathrm{X}_{3}$ & -0.08 & -0.53 & 0.59 \\
\hline Household Member & $\mathrm{X}_{4}$ & -0.30 & -1.66 & $* * 0.09$ \\
\hline Age & $\mathrm{X}_{5}$ & -0.01 & -2.11 & $* 0.03$ \\
\hline Domicile & $\mathrm{X}_{6}$ & -0.46 & -2.89 & $* 0.00$ \\
\hline Agricultural Sector & $\mathrm{X}_{7}$ & 0.00 & 0.01 & 0.99 \\
\hline Industrial Sector & $\mathrm{X}_{8}$ & 0.19 & 0.57 & 0.57 \\
\hline Service Sector & $\mathrm{X}_{9}$ & -0.48 & -1.36 & 0.17 \\
\hline Marital Status & $\mathrm{X}_{10}$ & -0.73 & -2.64 & $* 0.00$ \\
\hline Gender & $\mathrm{X}_{11}$ & 1.03 & 2.89 & $* 0.00$ \\
\hline \multicolumn{1}{c}{ Constanta } & & 0.81 & 1.37 & 0.17 \\
\hline
\end{tabular}

Source: Susenas 2020 processed using STATA

\section{Parameter Estimates of Food-Insecure Households}

The results of the wald (z) test showed that some factors such as wages, employment, household members, agricultural sector, industrial sector, and service sector significantly affect the level of food security, this is evidenced in the consecutively of the wald test $(\mathrm{z})$ value known as $-6.41 ;-1.71 ;-2.87 ;-1.95 ;-1.65 ;-2.03$ with $\mathrm{P}$ value of $\mathrm{P}>|\mathrm{z}|$ known as $0.00 ; 0.08 ; 0.00 ; 0.05 ; 0.09 ; 0.04$ are smaller than alpha $5 \%(0.05)$. More results are presented in table 7 below:

Table 7. Parameter Estimates on Food Insecure Households

\begin{tabular}{llrrr}
\hline Variable & Notation & Coefficient & Wald (z) & $\mathbf{P}>\mid \mathbf{z}$ \\
\hline Wages & $\mathrm{X}_{1}$ & -4.23 & -6.41 & $* 0.00$ \\
\hline Education & $\mathrm{X}_{2}$ & -0.59 & -1.41 & 0.15 \\
\hline Employment & $\mathrm{X}_{3}$ & -0.69 & -1.71 & $* * 0.08$ \\
\hline Household Member & $\mathrm{X}_{4}$ & -1.00 & -2.87 & $* 0.00$ \\
\hline Age & $\mathrm{X}_{5}$ & 0.01 & 1.01 & 0.31 \\
\hline Domicile & $\mathrm{X}_{6}$ & -0.16 & -0.48 & 0.63 \\
\hline Agricultural Sector & $\mathrm{X}_{7}$ & -1.18 & -1.95 & $* 0.05$ \\
\hline Industrial Sector & $\mathrm{X}_{8}$ & -1.07 & -1.65 & $* * 0.09$ \\
\hline Service Sector & $\mathrm{X}_{9}$ & -1.33 & -2.03 & $* 0.04$ \\
\hline Marital Status & $\mathrm{X}_{10}$ & -0.89 & -1.17 & 0.24 \\
\hline Gender & $\mathrm{X}_{11}$ & 0.64 & 0.77 & 0.44 \\
\hline \multicolumn{1}{c}{ Constanta } & & 3.51 & 2.85 & 0.00 \\
\hline
\end{tabular}

Source: Susenas 2020 processed using STATA

\subsubsection{Relative Risk Ratio (odds ratio)}

Note: **significant at $10 \% *$ significant at $5 \%$

The relative risk ratio conducted to analyze how much ratio of tendency/opportunity of each independent variables that proven have significant effect for more food secure in each following household

\section{Relative Risk on Food-Vulnerable Households for more Food Secure}

Based on parameter estimates test, there are five factors that significantly affect food security of food-vulnerable households, such as: wages, employment, household members, age, and the service sector. Here's an explanation of each factor:

Wage factor has a negative coefficient value of -1.34 and a relative risk ratio value of 0.99 means that each wage fluctuation of 1 unit, will decrease household's opportunities being more food secure by 1.34 times (134\%). The tendency of wage fluctuation factors for more food secure is $0.99(99 \%)$ assuming other variables are held constant.

Employment status of household's head has a positive coefficient value of 0.4 and a relative risk ratio value of 1.5 means that each head of household employed as an entrepreneur, will increase household's opportunities being more food secure by 0.4 times $(40 \%)$. The tendency of employment status as entrepreneurs for more food secure is $1.5(150 \%)$ assuming other variables are held constant.

Household Member has a negative coefficient value of -0.73 and a relative risk ratio value of 0.48 means that every household consisting of less than 4 people will decrease household's opportunities being more food secure by 0.73 times $(0.73 \%)$. The tendency of household member consisting of less than 4 people for more food secure is $0.48(48 \%)$ assuming other variables are held constant. 
Age of household's head has a negative coefficient value of -0.02 and a relative risk ratio value of 0.97 means that more years of household's head ages, will decrease the household's opportunity being more food secure by 0.02 times $(2 \%)$. The tendency of household's head ages for more food secure is $0.97(97 \%)$ assuming other variables are held constant.

Service Sector has a positive coefficient value of 0.6 and a relative risk ratio value of 1.83 means that every household Employed in the service sector, will increase household's opportunities being more food secure by 0.6 times $(60 \%)$. The tendency of service sector for more food secure is $1.83(183 \%)$ assuming other variables are held constant. More result of the relative risk (odds ratio) for each variable in food-vulnerable households for more food secure are presented in table 8 below:

Table 8. Relative Risk on Food-Vulnerable Households for more Food Secure

\begin{tabular}{llrrr}
\hline Variable & Notation & Coefficient & Relative Risk & $\mathbf{P}>|\mathbf{z}|$ \\
\hline Wages & $\mathrm{X}_{1}$ & -1.34 & 0.99 & $* 0.00$ \\
\hline Education & $\mathrm{X}_{2}$ & 0.01 & 1.01 & 0.95 \\
\hline Employment & $\mathrm{X}_{3}$ & 0.40 & 1.50 & $* 0.01$ \\
\hline Household Member & $\mathrm{X}_{4}$ & -7.73 & 0.48 & $* 0.00$ \\
\hline Age & $\mathrm{X}_{5}$ & -0.02 & 0.97 & $* 0.00$ \\
\hline Domicile & $\mathrm{X}_{6}$ & -0.03 & 0.96 & 0.82 \\
\hline Agricultural Sector & $\mathrm{X}_{7}$ & -0.28 & 0.75 & 0.44 \\
\hline Industrial Sector & $\mathrm{X}_{8}$ & 0.41 & 1.51 & 0.26 \\
\hline Service Sector & $\mathrm{X}_{9}$ & 0.60 & 1.83 & $* * 0.10$ \\
\hline Marital Status & $\mathrm{X}_{10}$ & 0.31 & 1.37 & 0.41 \\
\hline Gender & $\mathrm{X}_{11}$ & 0.21 & 1.23 & 0.61 \\
\hline \multicolumn{1}{c}{ Constanta } & & 1.68 & 5.37 & 0.00 \\
\hline
\end{tabular}

Source: Susenas 2020 processed using STATA

Note: $* *$ significant at $10 \% *$ significant at $5 \%$

Relative Risk on Food-Less Secure Households for more Food Secure

Based on parameter estimates test, there are seven factors that significantly affect food security of food-less secure households, the seven factors are: wages, education, household members, age, domicile, marital status, and gender. Here's an explanation of each factor:

Wage has a negative coefficient value of -3.79 and a relative risk ratio value of 0.99 means that each wage fluctuation of 1 unit, will decrease household opportunities being more food secure by 3.79 times (379\%). The tendency of wage fluctuation factors for more food secure is $0.99(99 \%)$ assuming other variables are held constant.

Education has a negative coefficient value of -0.62 and a relative risk ratio value of 0.53 means that every head of household educated higher than high school, vocational school, diploma and even bachelor, will decrease household's opportunities being more food secure by 0.62 times $(62 \%)$. The tendency of education levels above high school, vocational school, diploma even bachelor for more food secure is $0.53(53 \%)$ assuming other variables are held constant.

Household Member has a negative coefficient value of -0.3 and a relative risk ratio value of 0.73 means that each household consisting of less than 4 people, will decrease household's opportunities being more food secure by 0.3 times $(30 \%)$. The tendency of household member consisting of less than 4 people for more food secure is $0.73(73 \%)$ assuming other variables are held constant.

Age of household's head has a negative coefficient value of -0.01 and a relative risk ratio value of 0.98 means that more years that more years of household's head ages, will decrease the household's opportunities being more food secure by $0.01(1 \%)$. The tendency of household's head ages for more food secure is $0.98(98 \%)$ assuming other variables are held constant.

Domicile has a negative coefficient value of -0.46 and a relative risk ratio value of 0.62 means that every food-less secure household which domiciled in Kutai Kartanegara, will decrease household's opportunities being more food secure by 0.46 times $(46 \%)$. The tendency of household domicile for more food secure is $0.62(62 \%)$ assuming other variables are held constant.

Marital Status of household's head has a negative coefficient value of -0.73 and a relative risk ratio value of 0.47 means that the head of the household with "married" marital status, will decrease household's opportunities being more food secure by 0.73 times $(73 \%)$. The tendency of marital status for more food secure is $0.47(47 \%)$ assuming the other variables are held constant.

Gender of household's head has a positive coefficient value of 1.03 and a relative risk ratio value of 2.8 means that each household headed by a male, will increase the household's opportunities being more food secure by 1.03 times (103\%). The tendency household's head for more food secure is $2.80(280 \%)$ assuming other variables are held constant. More result of the relative risk (odds ratio) for each variable in food-less secure households for more food secure are presented in table 9 below: 
Table 9. Relative Risk Less on Food-Less Secure Households for more Food-Secure

\begin{tabular}{|c|c|c|c|c|}
\hline Variable & Notation & Coefficient & Relative Risk & $\mathbf{P}>|\mathbf{z}|$ \\
\hline Wages & $\mathrm{X}_{1}$ & -3.79 & 0.99 & $* 0.00$ \\
\hline Education & $\mathrm{X}_{2}$ & -0.62 & 0.53 & $* 0.00$ \\
\hline Employment & $\mathrm{X}_{3}$ & -0.08 & 0.91 & 0.59 \\
\hline Household Member & $\mathrm{X}_{4}$ & -0.30 & 0.73 & $* * 0.09$ \\
\hline Age & $\mathrm{X}_{5}$ & -0.01 & 0.98 & $* 0.03$ \\
\hline Domicile & $\mathrm{X}_{6}$ & -0.46 & 0.62 & $* 0.00$ \\
\hline Agricultural Sector & $\mathrm{X}_{7}$ & 0.00 & 1.00 & 0.99 \\
\hline Industrial Sector & $\mathrm{X}_{8}$ & 0.19 & 1.21 & 0.57 \\
\hline Service Sector & $\mathrm{X}_{9}$ & -0.48 & 0.61 & 0.17 \\
\hline Marital Status & $\mathrm{X}_{10}$ & -0.73 & 0.47 & $* 0.00$ \\
\hline Gender & $\mathrm{X}_{11}$ & 1.03 & 2.80 & $* 0.00$ \\
\hline \multicolumn{2}{|c|}{ Constanta } & 0.81 & 2.25 & 0.17 \\
\hline
\end{tabular}

Source: Susenas 2020 processed using STATA

Note: $* *$ significant at $10 \% *$ significant at $5 \%$

Relative Risk on Food-Insecure Households for more Food Secure

Based on parameter estimates test, there are six factors that significantly affect the level of food security of food insecure households, the six factors in question are: wages, employment, household members, agricultural sector, industrial sector, and service sector. Here is an explanation for each factor:

Wage has a negative coefficient value of -4.23 and a relative risk ratio value of 0.99 means that each wage fluctuation of 1 unit, will decrease household's opportunities being more food secure by 4.23 times (423\%). The tendency of wage fluctuation for more food secure is $0.99(99 \%)$ assuming other variables are held constant.

Employment status household's head has a negative coefficient value of -0.69 and a relative risk ratio value of 0.5 means that each head of household employed as an entrepreneur, will decrease household's opportunities being more food secure by 0.69 times $(69 \%)$. The tendency of employment status as entrepreneurs for more food secure is $0.5(50 \%)$ assuming other variables are held constant.

Household Member has a negative coefficient value of -1 and a relative risk ratio value of 0.36 means that each household consisting of less than 4 people, will decrease the household's opportunities being more food secure by 1 time (100\%). The tendency of household member consisting of less than 4 people for more food secure is $0.36(36 \%)$ assuming other variables are held constant.

Agricultural has a negative coefficient value of -1.18 and a tendency ratio value of 0.3 means that every household employed in agricultural sector, will decrease the household's opportunities being more food secure by 1.18 times $(118 \%)$. The tendency agricultural sector for more food secure is $0.3(30 \%)$ assuming other variables are held constant.

Industrial Sector has a negative coefficient value of -1.07 and a relative risk ratio value of 0.34 means that every household employed in industrial sector, will decrease household's opportunities being more food secure by 1.07 times $(107 \%)$. The tendency of industrial sector for more food secure is $0.34(34 \%)$ assuming other variables are held constant.

Service Sector has a negative coefficient value of -1.33 and a relative risk ratio value of 0.26 means that every household employed in service sector, will decrease household's opportunities being more food secure by 1.33 times $(133 \%)$. The tendency of service sector for more food secure is $0.26(26 \%)$ assuming other variables are held constant. More result of the relative risk (odds ratio) for each variable in food-insecure households for more food secure are presented in table 10 below: 
Table 10. Relative Risk on Food-Insecure Households for more Food Secure

\begin{tabular}{|c|c|c|c|c|}
\hline Variable & Notation & Coefficient & Relative Risk & $\mathbf{P}>|\mathbf{z}|$ \\
\hline Wages & $\mathrm{X}_{1}$ & -4.23 & 0.99 & $* 0.00$ \\
\hline Education & $\mathrm{X}_{2}$ & -0.59 & 0.55 & 0.15 \\
\hline Employment & $\mathrm{X}_{3}$ & -0.69 & 0.50 & $* * 0.08$ \\
\hline Household Member & $\mathrm{X}_{4}$ & -1.00 & 0.36 & $* 0.00$ \\
\hline Age & $\mathrm{X}_{5}$ & 0.01 & 1.01 & 0.31 \\
\hline Domicile & $\mathrm{X}_{6}$ & -0.16 & 0.84 & 0.63 \\
\hline Agricultural Sector & $\mathrm{X}_{7}$ & -1.18 & 0.30 & $* 0.05$ \\
\hline Industrial Sector & $\mathrm{X}_{8}$ & -1.07 & 0.34 & $* * 0.09$ \\
\hline Service Sector & $\mathrm{X}_{9}$ & -1.33 & 0.26 & $* 0.04$ \\
\hline Marital Status & $\mathrm{X}_{10}$ & -0.89 & 0.40 & 0.24 \\
\hline Gender & $\mathrm{X}_{11}$ & 0.64 & 1.89 & 0.44 \\
\hline \multicolumn{2}{|l|}{ Constanta } & 3.51 & 33.45 & 0.00 \\
\hline
\end{tabular}

Source: Susenas 2020 processed using STATA

Note: **significant at $10 \% *$ significant at $5 \%$

\subsection{Discussion}

Based on the results of the analysis of factors that significantly affect households' food security level, especially food-vulnerable households, food-less secure households, and food-insecure households, it is known that factors of wages, education, employment, household members, age, domicile, agricultural sector, industrial sector, service sector, marital status, and gender significantly affect food security levels. Here is a complete explanation of each of these variables:

Wages based on research results that any significant fluctuations in wages have negatively affect for level of household's food security at all household's categories according to food security level, this indicates that household spending patterns have not been directed so they tend to be wasteful in spending their wages and they are unable to prioritize food spending first, cigarette spending is suspected to be the cause of their wasteful expense.

Education based on research results that the high level of education of household's head significantly negatively affects for level of food security at food-less secure households, this indicates that there are less available vacancies for jobseeker with higher education, so they are forced to take jobs with low educational qualifications. Meanwhile education level of household's head does not significant affect for level of food security at food-insecure households and food-vulnerable households.

Employment based on research results that status of employment as an entrepreneur significantly negatively affects for level of food security at food-insecure households, this indicates that they are more prosperous if they work as employees. While this research also resulted that employment status as an entrepreneur significantly positively affects for level of food security at food-vulnerable households, it indicates that food-vulnerable households will be more prosperous if work as entrepreneurs. Meanwhile employment status as an entrepreneur do not significant affected for level of food security at food-less secure households.

Household Members based on research results that households consisting less than 4 people significantly negatively affect for food security level at all household's categories according to food security level, this indicates that each household consisting of less than 4 people there is only one member who work to make a living for the entire household, so it is very relevant if fewer household members will decrease the opportunity being more food secure because only one member who work in the household.

Age based on the research results that more years of household's ages significantly negatively affects for level of food security at food-less secure households and food-vulnerable households, this indicates that getting older will reduce ability to work also ability to move around so that it will reduce income earned. Meanwhile more years of household's age is not significantly affected for level of food security at food-insecure households.

Domicile based on the research results that households which domiciled in Kutai Kartanegara significantly negatively affect for level of food security at food-less secure households, this will certainly restrict access of nutritious food at households which domicile Kutai Kartanegara. Meanwhile factor of household's domicile is not significantly affected for level of food security at food-insecure households and food-vulnerable households.

The Agricultural Sector based on research results that agricultural sector business fields significantly negatively affect the level for food security at food-insecure households, this indicates that households will be more prosperous if they employed outside the agricultural sector. Meanwhile Agricultural sector business field has not significantly affected for level of food security at food-less secure households and food-vulnerable households.

The Industrial Sector based on research results that industrial sector business fields significantly negatively affecting for level of food security at food-insecure households, this indicates that household also no more prosperous if they employed in the industrial sector, so it is recommended that they work outside the industrial 
sector. Meanwhile industrial sector business field has not significantly affected for level of food security at foodless secure households and food-vulnerable households.

The Service Sector based on the research results that the service sector business field significantly negatively affects for level of food security at food-insecure households, but it is even significantly affects for level of food security at food-vulnerable households. This indicates that food-insecure households are more prosperous if employed outside the service sector, maybe they are more prosperous if employed in mining sector, but service sector business field is best choice for food-vulnerable households. Meanwhile service sector business field has not significantly affected for level of food security at food-less secure household.

Marital Status based on research results that the marital status "married" of household's head significantly negatively affects for level of food security at food-less secure households, this indicates that households which less food will be more prosperous if they are able to delay their marriage, hoping that being single will increase opportunities being more food secure. Meanwhile the marital status "married" does not significantly affect for level of food security at food-insecure households and food-vulnerable households.

Gender based on research results that household headed by male has positively affects for level of food security at food-less secure household, this indicate that they will be more prosperous if they led by male as head of households rather than female. Meanwhile household's gender does not significantly affect for level of food security at food-insecure households and food-vulnerable households.

\section{Conclusion}

Based on an analysis of factors that significantly affect the level of household food security using multinomial logistic regression shows that factors of wages, education, employment, household members, age, domicile, agricultural sector, industrial sector, service sector, marital status, and gender significantly affect the level of food security in each household. More influence of each factor on food security levels is presented in table 11 below:

Table 11. Significant factors affect the level of household food security

\begin{tabular}{lrrrr}
\hline \multirow{2}{*}{ Factors } & \multicolumn{3}{c}{ Effect on Household } \\
\cline { 2 - 5 } & Food-Insecurity & Food-Less Secure & Food-Vulnerable \\
\hline Wages & -1 & -1 & -1 \\
\hline Education & 0 & -1 & 0 \\
\hline Employment & -1 & 0 & 1 \\
\hline Household Member & -1 & -1 & -1 \\
\hline Age & 0 & -1 & -1 \\
\hline Domicile & 0 & -1 & 0 \\
\hline Agricultural Sector & -1 & 0 & 0 \\
\hline Industrial Sector & -1 & 0 & 0 \\
\hline Service Sector & -1 & 0 & 1 \\
\hline Status & 0 & -1 & 0 \\
Marriage & 0 & 1 & 0 \\
\hline Gender & & & \\
\hline
\end{tabular}

Source: Susenas 2020 processed using STATA

Information:

Significant positive effect: 1

Significant negative effect: -1

No significant effect: 0

\section{Policy Recommendation}

Here are some policy recommendations for government that plans to move the capital city and its relation to level of household food security in Kutai Kartanegara Regency and North Penajam Paser Regency:

It is recommended to loosen the requirements of consumption credits for households with a certain minimum wage, hoping that household's opportunities being more food secure are not decreased when there are fluctuations in wages. Because, the results showed that wage factors significantly negatively affect food security levels.

It is recommended to provide more jobs for local people who are educated above high school, vocational school, diploma and even bachelor because, hoping that highly educated people get more decent jobs and in accordance with the classification of their education level. Because, the results showed that educational factors significantly negatively affect the level of food security.

It is recommended to loosen microcredit requirements for people's businesses, especially for local micro, small and medium enterprises engaged in the real sector, hoping that the household industry would develops and able to absorb labor from the surrounding community. Because, the results showed that the factor of employment status as an entrepreneur significantly negatively affects the level of food security. 
It is recommended to increase the amount of food with agricultural intensification efforts so that household opportunities at Kutai Kartanegara being more food secure increase. Because, the results showed that households domiciled in Kutai Kartanegara significantly negatively affect for level of food security.

To further researchers who have a research interest in food security, it is advisable to add new variables to the model, allegedly variables such as poor rice assistance (beras miskin), household assets, compensation for the construction of capital city office complexes, and mining sector business fields have significantly positive affect for food security level.

\section{Acknowledgements}

The researcher thanked the Service and Promotion Director of the Central Statistics Agency (Badan Pusat Statistik) of Republic Indonesia for granting researcher request of data for the purposes of this research, also for service excellent for this time being.

\section{Reference}

Abdullah, Zhou, D., Shah, T., Ali, S., Ahmad, W., Din, I. U., \& Ilyas, A. (2019). Factors affecting household food security in rural northern hinterland of Pakistan. Journal of the Saudi Society of Agricultural Sciences, 18(2), 201-210. doi: 10.1016/J.JSSAS.2017.05.003

Abdurehim, A., \& Ejigu, H. (2021). Food Security Status and Its Determinants among Rural Households in Oda Bultum District, West Hararghe Zone, Oromia National Regional State, Ethiopia. Journal of Economics and Sustainable Development. doi: 10.7176/JESD/12-17-03

Anisya, A. P. M., \& Waluyati, L. R. (2019). Peluang Desa Lumbung Pangan dalam Meningkatkan Ketahanan Pangan Rumah Tangga Tani. AGRARIS: Journal of Agribusiness and Rural Development Research, 5(2), 151-161. doi: 10.18196/AGR.5284

BKP-RI. (2019). STATISTIK KETAHANAN PANGAN 2019.

BPS-RI. (2018). Proyeksi Penduduk Indonesia 2015-2045 (Direktorat Statistik Kependudukan dan Ketenagakerjaan BPS \& Kementrian PPN/Bappenas, Eds.). Jakarta: PT Gandewa Pramatya Arta.

Fitriani, M. I., Prasmatiwi, F. E., \& Adawiyah, R. (2020). Ketahanan Pangan Rumah Tangga Petani Anggota Lumbung di Kecamatan Gading Rejo, Kabupaten Pringsewu. Jurnal Ilmu Ilmu Agribisnis: Journal of Agribusiness Science, 8(4), 673-680. doi: 10.23960/JIIA.V8I4.4713

Herdiana, A., Darwanto, D. H., \& Mulyo, J. H. (2014). KETAHANAN PANGAN RUMAH TANGGA DI KABUPATEN CIAMIS. SEPA: Jurnal Sosial Ekonomi Pertanian Dan Agribisnis, 11(1), 21-34. doi: 10.20961/sepa.v11i1.42247

Hernanda, E., Indriani, Y., \& Kalsum, U. (2017). Pendapatan Dan Ketahanan Pangan Rumah Tangga Petani Padi di Desa Rawan Pangan | Hernanda | Jurnal Ilmu Ilmu Agribisnis: Journal of Agribusiness Science. JIIA: Jurnal Ilmu Agribisnis, 283-291.

Jianguo Liu, Vanessa Hull, Mateus Batistella, Ruth DeFries, Thomas Dietz, Feng Fu, Thomas W. Hertel, R. Cesar Izaurralde, Eric F. Lambin, Shuxin Li, Luiz A. Martinelli, William J. McConnell, Emilio F. Moran, Rosamond Naylor, Zhiyun Ouyang, Karen R. Polenske, Anette Reenberg, Gilberto de Miranda Rocha, Cynthia S. Simmons, ... Fusuo Zhang and Chunquan Zhu. (2013). Framing Sustainability in a Telecoupled World. JSTOR.

Jonsson, \& Toole. (1991). Conceptual analysis of resources and resource. UNICEF.

Murniati, \& A. Nunuk P. (2004). Getar gender (Vol. 1). Magelang: Indonesia Terra.

Nanda, L. P., Mulyo, J. H., \& Waluyati, L. R. (2019). Analisis Ketahanan Pangan Rumah Tangga di Kabupaten Lampung Tengah. Jurnal Ekonomi Pertanian Dan Agribisnis, 3(2), 219-232. doi: 10.21776/UB.JEPA.2019.003.02.1

Permenkes 28 Tahun 2019 tentang AKG. (2019). Peraturan Menteri Kesehatan Nomor 28 Tahun 2019 tentang Angka Kecukupan Gizi yang Dianjurkan untuk Masyarakat Indonesia (No. 28). Jakarta: BN.2019/NO.956, PERATURAN.GO.ID: 5 HLM.

Suharyanto, Mulyo, J. H., Darwanto, D. H., \& Widodo, S. (2014). Determinants of Food Security Among Rice Farming Households in the Province of Bali: An Ordered Logistic Model. Journal of Economics and Sustainable Development, 5(8), 35-42.

Syamola, D., \& Nurwahyuni, A. (2019). Determinan Ketahanan Pangan Rumah Tangga di Daerah Pedesaan di Indonesia (Analisis Data Susenas Tahun 2017). Media Kesehatan Masyarakat Indonesia, 15(1), 46. doi: 10.30597/MKMI.V15I1.5880

Undang-undang Nomor 18 Tahun 2012 tentang Pangan. (2012). Undang-undang Nomor 18 Tahun 2012 tentang Pangan (No. 18). Jakarta: LN.2012/No. 227, TLN No. 5360, LL SETNEG: 58 HLM.

Undang-undang Nomor 52 Tahun 2009 tentang Perkembangan Kependudukan dan Pembangunan Keluarga. (2009). UU No. 52 Tahun 2009 tentang Perkembangan Kependudukan dan Pembangunan Keluarga (No. 52). Jakarta: LN. 2009/ No. 161, TLN NO. 5080, LL SETNEG : 36 HLM. 
Warr, P. G. (2014). Food Insecurity and its Determinants. Australian Journal of Agricultural and Resource Economics, 58(4), 519-537. doi: 10.1111/1467-8489.12073 